\title{
ESTRATÉGIAS PEDAGÓGICAS NORTEADAS POR METODOLOGIAS ATIVAS NO ENSINO DE CIÊNCIAS NATURAIS
}

\author{
Jackson Nunes da Silva ${ }^{1}$ \\ Andreia Aparecida Guimarães Strohschoen ${ }^{2}$
}

\begin{abstract}
Resumo: Este artigo tem como objetivo o desenvolvimento de um estudo baseado em metodologias ativas, na área de Ciências Naturais. Para isso, foram pesquisadas e desenvolvidas com alunos, duas estratégias pedagógicas ativas: o 'World café' e o Grupo de verbalização e Grupo de Observação (GV/GO). Inicialmente, foi realizada uma pesquisa bibliográfica acerca de metodologias ativas e sua importância no desenvolvimento de aulas de Ciências Naturais. Desenvolveu-se aulas em uma turma do $6^{\circ}$ ano do Ensino Fundamental de uma escola do município de Macapá/Amapá, adotandose como foco as duas estratégias supracitadas. $\mathrm{O}$ resultado que obtivemos foi promissor, pois os estudantes alcançaram um excelente nível de envolvimento e engajamento nas atividades de ambas as estratégias pedagógicas, demonstrando estar realmente buscando o aprender a aprender, estando envolvidos na construção de conhecimentos científicos. As estratégias foram avaliadas positivamente pelos estudantes, podendo-se vislumbrar, a partir dessa experiência, que é possível traçar um caminho promissor no ensino de Ciências Naturais.
\end{abstract}

Palavras-chave: Metodologias ativas. Ciências Naturais. 'World café'. GV/GO.

\section{PEDAGOGICAL STRATEGIES GUIDED BY ACTIVE METHODOLOGIES IN THE TEACHING OF NATURAL SCIENCES}

\begin{abstract}
This article aims to develop a study based on active methodologies in the field of Natural Sciences. For this, two active pedagogical strategies were researched and developed with students: 'World café' and Verbalization Group and Observation Group (GV/GO). Initially, a bibliographic research was carried out on active methodologies and their importance in the development of Natural Science classes. Classes were developed in a group of the 6th year of elementary school at a school in the city of Macapá/Amapá, adopting the two aforementioned strategies as a focus. The result we
\end{abstract}

1 Biólogo. Mestre em Ensino de Ciências Exatas/Univates.

2 Professora dos Programas de Pós graduação: Doutorado e Mestrado em Ensino (PPGEnsino) e Doutorado e Mestrado Profissional em Ensino de Ciências Exatas (PPGECE). Pesquisadora em Ensino de Ciências e Biologia, Iniciação à Pesquisa, Metodologias Ativas de Ensino e de Aprendizagem. Universidade Vale do Taquari - Univates. 
obtained was promising, as the students reached an excellent level of involvement and engagement in the activities of both pedagogical strategies, demonstrating that they were really looking for learning to learn, being involved in the construction of scientific knowledge. The strategies were positively evaluated by the students, and it is possible to glimpse, from this experience, that it is possible to trace a promising path in the teaching of Natural Sciences.

Keywords: Active methodologies. Natural Sciences. 'World café'. GV/GO.

\section{Introduçáo}

Nesta pesquisa, abordaremos, inicialmente, as metodologias ativas, tecendo um pouco de seu conceito e também de sua importância no ensino. Em seguida, abordaremos o uso dos métodos ativos no ensino de ciências, elencaremos algumas formas de colocar a metodologia ativa em prática, enfatizando as estratégias 'World café' e GV/GO.

Numa breve reflexão, Lopes e Macedo (2016), traçam um panorama sobre a evolução da educação ao longo do tempo e mostram como é possível perceber que há poucas diferenças entre a educação em séculos anteriores e o século XXI. A educação é uma das coisas que pouco tem se adaptado às mudanças ocorridas com o passar do tempo, pois apesar da comprovação dos diversos meios de aprendizagem, dos diversos recursos possíveis para se efetivar o aprendizado do estudante, prevalece ainda, na maioria das escolas, a velha tradição do professor que explica e do estudante que apresenta-se passivo.

Malgrado, poucas adaptações são adotadas, impostas em momentos extremos, como é o caso da atual pandemia de Covid-19, que levou o sistema educacional a implantar mudanças drásticas, para que os estudantes continuassem suas atividades (MIRANDA et al., 2020). Muitas escolas, recorreram ao ensino virtualizado, remoto ou a distância. Os professores elaboraram materiais de estudo, gravação de videoaulas, organização de lives, etc, apropriando-se de tecnologias que o período nos oferece. Mas não se pode dizer que todas as escolas estáo fazendo proveito de tais recursos. O que dizer das regiōes que não têm ou têm um acesso precário à internet? $\mathrm{O}$ que dizer das escolas em que os estudantes apenas recebem as apostilas escritas, sem nenhuma orientação sobre o que fazer com as atividades? Será que podemos afirmar que, de fato, houve um salto nas metodologias aplicadas à educação?

Se por um lado, muitos estudantes aproveitam-se de tecnologias de 'ponta' para efetivar seus estudos, tendo acesso a laboratórios, a museus, a parques, a professores qualificados; por outro lado, para muitos outros estudantes, cabe apenas o ensino tradicional, com o quadro negro, o livro didático (quando há), professores desestimulados pelo sistema, escolas depredadas, etc (MIRANDA et al., 2020).

O que se observa é uma discrepância dentro do próprio sistema educacional brasileiro, em que o que está previsto nos documentos oficiais, o que rege os Currículos para o ensino de ciências, não consegue ser cumprido na íntegra e de forma efetiva em todo o território nacional. Isto pois, há escolas que não oferecem garantias para cumprimento do currículo, devido às diversas deficiências do próprio 
sistema educacional. Geralmente, o resultado disso é o fracasso escolar, uma vez que as metodologias aplicadas em sala de aula e no currículo - muitas vezes estáo aquém da realidade do estudante - e o sistema escolar já não correspondem aos anseios e necessidades dos estudantes.

Anos atrás, era comum pensar no estudante como um receptáculo vazio, pronto para ser preenchido pelo conhecimento portado pelo professor, o mestre e líder dentro da sala de aula. No entanto, com o advento do século XXI, o futuro da educação vem sendo questionado e muitos estudiosos e educadores já não veem mais o estudante como coadjuvante do aprendizado, mas como protagonista, produtor do conhecimento (LOPES; MACEDO, 2016).

Essa ideia, defendida, inclusive, por Paulo Freire (1996), direcionava-se para a necessidade de que, para que o conhecimento se efetivasse e se tornasse significativo para o estudante, seria necessário que este fosse fruto das suas próprias açóes, por meio da interaçáo com o meio e com os outros indivíduos. Dessa forma, Freire (1996) defende a autonomia do estudante diante da produção e construção do conhecimento, dado que o ser humano constitui-se socialmente por experiências às quais se adaptarão e se relacionarão os novos saberes adquiridos.

Percebe-se, então, a importância de novas metodologias para o ensino de Ciências Naturais, pois a inovação metodológica no ensino estimula a aprendizagem e a participaçáo do estudante na sala de aula, de modo que ele utilize todas as suas dimensôes de inteligência: sensório-motor, efetivo-emocional e mental-cognitivo. Dessa forma, essa pesquisa tem como objetivo analisar as potencialidades das estratégias pedagógicas norteadas por metodologias ativas, no ensino de Ciências Naturais, considerando o conteúdo de Ecologia no Ensino fundamental, anos finais, afim de se trabalhar o engajamento, a autonomia e a construção do conhecimento científico dos estudantes.

Buscando elucidar a questão norteadora, elencou-se como objetivos específicos: elaborar e desenvolver atividades relacionadas aos conteúdos de Ecologia, com o uso de duas estratégias de ensino ativas com a turma de estudantes do $6^{\circ}$ ano - Ensino Fundamental; e analisar as percepçóes dos estudantes, em relação à utilização das estratégias de ensino para o estudo de conteúdos de Ecologia.

Partindo do cumprimento de tais objetivos, acredita-se que será possível inverter os papéis do professor e dos estudantes na sala de aula, garantindo aos estudantes a autonomia para interagir com seus pares, pôr em prática o conhecimento teórico, dialogar com seus colegas e com o professor.

\section{Desenvolvimento}

As metodologias ativas podem ser consideradas açóes profícuas de serem aplicadas em sala de aula. Conhecê-las de forma mais aprofundada pode trazer mudanças significativas à escola. Dessa maneira, apresentamos as metodologias ativas de ensino e também discutimos sobre o uso destas no ensino de ciências naturais- anos finais, percebendo o papel ativo dos estudantes no ensino de ciências. 
Destarte, a BNCC (2018) - Base Nacional Comum Curricular - destaca a importância do sujeito no processo de aprendizagem, uma vez que este se caracteriza por ser um processo particular para cada indivíduo. Segundo tal documento, aprendizagem ocorre na interaçáo entre professor, estudante e conhecimento. Dessa maneira, a BNCC propóe que seja o professor um mediador entre os conhecimentos científicos e os conhecimentos prévios do estudante.

Em relação ao ensino de Ciências Naturais, sabe-se que o acesso aos conhecimentos propiciados pela área é fundamental para compreender o mundo. Assim, o ensino de ciências deve ser construído, cabendo à escola um importante papel nessa tarefa. É na escola que se deve incentivar a criança a adentrar o mundo científico, para que saiba que os fenômenos naturais têm uma explicaçáo pautada na ciência, não apenas em achismos ou senso comum. Dessa forma, esse estudante tenderá a se desenvolver curioso frente à pesquisa, questionador frente aos problemas que se lhe apresentam, não se conformando com respostas simplistas e reducionistas. É assim que se desenvolve um pensamento científico, a partir da experimentação, das pequenas pesquisas desenvolvidas na escola, das visitas aos ambientes que rodeiam o estudante, para mostrar-lhe o ecossistema ali presente, ou os problemas ambientais, ou até mesmo os fenômenos físicos ou químicos. A ciência está no cotidiano, e é dever da escola mostrar isso ao estudante.

Sendo assim, Brasil (2018), no intuito de desvincular o ensino de ciências da metodologia livresca, orienta que sejam realizadas metodologias diferenciadas, tais como a experimentação, observação, jogos, análise do cotidiano através de jornais e revistas, entre outros. A Base Nacional Comum Curricular (BNCC) de ciências da natureza reforça essa ideia, instituindo que o compromisso desta área é colaborar com a alfabetização científica ou letramento científico, na atuação do estudante como cidadão que age e transforma sua realidade, compreendendo e interpretando o mundo natural, social e tecnológico (BRASIL, 2018).

A busca de formas mais eficientes de se ensinar ciências é perceptível na importância que a BNCC dá a isso como um fator relevante na construção das relaçóes entre homem e natureza, culminando no desenvolvimento de uma consciência social, o que torna os estudantes cidadãos críticos, capazes de interpretar e avaliar as informaçôes que lhes chegam, agindo como atuantes e cientes de sua responsabilidade social, sustentabilidade e do bem comum (BRASIL, 2018).

Nesse sentido é que se originam as metodologias ativas, que colocam o estudante como centro da aprendizagem, conforme aponta Freire (1996), ao caracterizar a educaçáo como um processo que é realizado na interação entre os sujeitos através de palavras, açóes e reflexôes. Dessa forma, enquanto o método tradicional prioriza a transmissão de informaçóes e cuja figura central é o professor, no método ativo, o núcleo são os próprios estudantes, sendo o conhecimento construído de forma colaborativa.

Dessa maneira, o método ativo pressupóe uma postura ativa entre os estudantes, sendo estes compreendidos como sujeitos históricos, cujas experiências, vivências, saberes e opinióes são valorizados e tomados como ponto de partida para 
a construção do conhecimento (ARAÚJO, 2015). Como defende Bastos (2006), o método ativo tem como foco estimular autoaprendizagem e a curiosidade do estudante, para que este tenha o desejo de pesquisar, refletir e analisar as situaçóes que lhe são dadas, assumindo o professor o papel de facilitador.

Em tais metodologias, o estudante tem uma maior participação na sala de aula, já que lhe são exigidas variadas práticas e construçôes mentais, tais como leitura, produção textual, pesquisa, análise, posicionamento crítico, comparações, problematização, busca de soluções, curiosidades, vivências, trabalhar em colaboração e etc (SOUZA; IGLESIAS; PAZIN-FILHO, 2014; BACICH; MORAN, 2018).

Assim, o que se busca nas metodologias ativas é a autonomia do estudante, para que ele possa construir o conhecimento de forma independente e em colaboração com aqueles que estão a sua volta, não simplesmente absorver informaçóes que lhe são impostas, como o que ocorre no ensino tradicional (ABREU, 2009).

Berbel (2011, p. 29) também corrobora com essa perspectiva, acrescentando uma característica essencial ao exercício da autonomia:

O engajamento do aluno em relaçáo a novas aprendizagens, pela compreensão, pela escolha e pelo interesse, é condição essencial para ampliar suas possibilidades de exercitar a liberdade e a autonomia na tomada de decisóes em diferentes momentos do processo que vivencia, preparando-se para o exercício profissional futuro.

Ademais, a visão de Freire (2015) também está de acordo com essa perspectiva, justificando o histórico de fracasso escolar que marca a educação brasileira, por meio do fato de que os estudantes geralmente não são estimulados a pensar de forma autônoma. Durante anos, os estudantes foram tratados como receptáculos vazios, cuja responsabilidade seria decorar datas, fórmulas, fatos históricos, regras, mas não lhes era ensinado a pensar sobre o que aprendiam, caracterizava-se então um ensino vazio. Dessa forma, muito do que se aprendia na escola era esquecido ao se finalizar as atividades, avaliaçóes ou período letivo, justamente devido ao estudante não reconhecer naquele conteúdo a sua realidade.

Outrossim, Jófili (2002), acerca dessa problemática, aponta algumas ações a serem exercidas no ambiente escolar, tais como:

[...] assegurar um ambiente dentro do qual os alunos possam reconhecer e refletir sobre suas próprias ideias; aceitar que outras pessoas expressem pontos de vista diferentes dos seus, mas igualmente válidos e possam avaliar a utilidade dessas ideias em comparação com as teorias apresentadas pelo professor (JÓFILI, 2002, p. 196).

Assim, por meio da metodologia ativa, portanto, a problematização se torna essencial em sala de aula, dado que para se construir o conhecimento, é necessário desenvolver um olhar crítico para a realidade estudada, isso requer que o estudante seja instigado, é entáo que a figura do professor se destaca, ele será o responsável pela mediaçáo entre o estudante e o conhecimento, ele incentivará o estudante a buscar as respostas que supram suas curiosidades. 
Entretanto, para que isso se efetive, é preciso que o professor também seja curioso e tenha domínio do assunto abordado, bem como tenha conhecimento das ramificaçôes que determinado assunto possa ter (BERBEL, 2011). Esse conhecimento, no entanto, encontra uma barreira na fragmentação que os conteúdos sofreram nos currículos tradicionais, nos quais cada professor só tem conhecimento daquilo que se insere em sua disciplina.

É notável que, quando trabalhada de forma a prender a atenção do estudante e nele despertar relaçôes significativas, a disciplina de Ciências o ajuda a encontrar respostas para muitas questóes, antes despercebidas em seu cotidiano, leva-o a exercitar o raciocínio lógico, numa busca contínua pelo conhecimento. A tecnologia, táo presente em nosso dia a dia, só confirma a relevância da disciplina no processo de construção do conhecimento científico (BRASIL, 2018).

A fim de tornar o ensino de Ciências mais eficiente, é válido explorar metodologias alternativas, distanciando-se do ensino tradicional. Cabe ao professor despertar a curiosidade do estudante, do contrário, o aprendizado não se concretizará. Dessa forma, é imprescindível que o ensino de Ciências esteja comprometido com as questôes sociais, mostrando o vínculo entre ciência, tecnologia e sociedade (LORENZETTI; DELIZOICOV, 2001).

Contudo, uma falha que tem se repetido no decorrer do tempo é justamente essa ausência da contextualização do objeto ensinado. Os estudantes não conseguem identificar o que veem na escola nas práticas do cotidiano, o que torna a disciplina irrelevante para a maioria deles (OVIGLI; BERTUCCI, 2009). Ademais, muitos professores ainda se concentram no ensino por meio de aulas expositivas, tornando o estudante um sujeito passivo no processo do aprender. Essa combinaçáo de descontextualizaçáo e monotonia das aulas faz com que muitos estudantes se tornem alheios ou avessos àquilo que está sendo ministrado.

Mas ainda há aqueles professores que buscam novos olhares sobre o ensino de Ciências, na tentativa de resgatar o significado pretendido pela disciplina. Como apontam Mortimer e Scott (2002), há muitas formas de se abordar os conteúdos de Ciências, aproximando es estudantes do conhecimento científico.

O aprendizado, entáo, está relacionado à vida prática, à vivência, conforme aponta Freire (1996), ademais, ele não deve se limitar ao conhecimento específico do assunto ensinado. Aprende-se para a vida, e ao mesmo tempo em que se ensina conteúdos de ciência, é possível praticar a tolerância, o respeito e a cidadania:

Os estudantes aprendem o que vivenciam. Se os estudantes convivem com as consequências de seus atos - são responsáveis, corresponsáveis pelo seu processo de aprendizagem - aprendem a se tornar responsáveis. Se convivem com expectativas positivas, aprendem a construir um mundo melhor. Se convivem com o respeito no trabalho em grupo e nos salóes compartilhados, aprendem a ter consideraçáo pelos outros. Se convivem com o apoio de educadores e de outros estudantes, aprendem a apoiar e a se aceitar melhor. Se convivem com a responsabilidade, aprendem a ser autossuficientes (MORAIS et al., 2018, p. 571). 
Elencou-se para este estudo duas estratégias pedagógicas, a saber 'World cafe' e GV/GO, considerando a estratégia 'World café', esta foi elaborada por Brown e Isaacs (2007) e se baseia na compreensão de que o diálogo é o principal elemento no processo de impulsionamento de negócio pessoais e organizacionais (CAFE WORLD COMMUNITY FUNDATION, 2011). Um dos pressupostos da estratégia 'World café' é que o conhecimento e a sabedoria necessários para se produzir ideias já estão presentes e acessíveis nos indivíduos; "a inteligência que emerge quando o sistema se conecta a si próprio de formas criativas" (BROWN; ISAACS, 2007, p. 185); ademais, a percepção é coletiva.

O 'World café' é desenvolvido em um ambiente descontraído e bemhumorado, com doses comedidas de irreverência e pressão, a fim de despertar a criatividade dos envolvidos, em busca de geração de ideias baseadas na colaboração entre os indivíduos. Dessa forma, pode-se dizer, que o foco desta estratégia é a produçáo de ideias num processo colaborativo (BROWN; ISAACS, 2007).

Tal estratégia pedagógica vem sendo adotada em vários países, visando potencializar diálogos e possibilitar a construção coletiva de ideias em torno de temas relevantes em diversos campos do conhecimento. Ademais, o 'World café' valoriza a criação de um espaço para o diálogo, por meio de questionamentos, o que estimula a participação dos sujeitos envolvidos, emitindo opinióes que favorecem a construção coletiva da compreensão de um determinado tema apresentado à discussão (BROWN; ISAACS, 2007).

Conforme o documento disponibilizado pelo The World Cafe Community (2015), para se realizar o 'World café', é necessário estabelecer grupos de aproximadamente quatro pessoas para a discussáo de temas previamente estabelecidos, a fim de se compreender ou responder a um determinado problema. Separados em subgrupos, deve ser estabelecido aos participantes cerca de vinte a trinta minutos para que realizem a exposição de suas ideias acerca dos temas disparadores das rodadas de diálogo, definidos em cada mesa de discussão. Ademais, cada mesa deve escolher um anfitriáo, que será o responsável pelo registro das questóes consideradas mais importantes pelo grupo ao longo da discussão.

Já a estratégia GV/GO consiste em uma estratégia de ensino e aprendizagem em que os envolvidos no processo sáo divididos em dois subgrupos: GV, Grupo de verbalização; e GO, Grupo de Observação (ANASTASIOU; ALVES, 2004). O primeiro grupo levantará uma discussão acerca de um determinado tema, enquanto o segundo o observa. Em seguida, há a substituição das funçóes, o que antes debatia, passa a observar e o que antes observava, liderará a discussão. Tal método pode ser usado para a discussão de um problema, para introduzir um novo conteúdo em sala de aula, para se buscar a solução de uma problemática, para estimular a participação dos estudantes num trabalho em equipe, ou mesmo para estimular suas habilidades de observação e julgamento.

O conceito da estratégia GV/GO utilizado neste estudo fundamenta-se na concepção de Anastasiou e Alves (2004). Para as autoras, tal estratégias consiste: 
[...] na análise de tema/problemas sob a coordenação do professor, que divide os estudantes em dois grupos: um de verbalização $(\mathrm{GV})$ e outro de observação (GO). É uma estratégia aplicada com sucesso ao longo do processo de construção do conhecimento e requer leituras, estudos preliminares, enfim, um contato inicial com o tema (ANASTASIOU; ALVES, 2004, p. 88).

Cada estratégia de ensino tem objetivos que guiam os estudantes no desenvolvimento de suas habilidades. Por meio da estratégia GV/GO, os estudantes podem desenvolver habilidades como análise e interpretação, pensamento crítico, levantamento de hipóteses, obtenção e organização de dados, comparação, resumo, observação, interpretação (ANASTASIOU; ALVES, 2004, p. 88).

GV/GO caracteriza-se por ser flexível, adaptando-se ao número de participantes da atividade. Em turmas pequenas, pode haver alternância entre o GV e o GO, já em turmas maiores, as autoras aconselham a subdivisão dos grupos em GV/GO, de modo que todos os participantes se envolvam na atividade (ANASTASIOU; ALVES, 2004)

Acerca do desenvolvimento de tal estratégia, Libâneo (2011, p. 171) explica que uma das principais funçôes do GO é verificar "[...] se os conceitos empregados na discussão são corretos, se os colegas estáo sabendo ligar a matéria nova com a matéria velha, se todos estão participando, etc.” Tais pontos são relevantes pois podem ser aproveitados pelo professor para avaliar o nível de aprendizagem e compreensão dos estudantes.

Um ponto de relevante de tal estratégia é a proposta do debate, da troca de idéias e experiências entre os estudantes. Segundo Masetto (2012), tal estratégia tem como propósito fundamental:

[...] permitir ao aluno expressar-se em público, apresentando suas ideias, reflexões, experiências e vivências, ouvir os outros, dialogar, respeitar opiniōes diferentes da sua, argumentar e defender suas próprias posiçóes (MASETTO, 2012, p. 114).

Ainda segundo Masetto, por intermédio do debate, a aprendizagem se torna mais eficaz, assim, tal estratégia traz contribuiçóes significativas para a estratégia GV/GO e para a construção científica e social dos estudantes, uma vez que provoca o exercício de se elaborar opinióes, saber ouvir e respeitar a fala do colega.

Para a etapa de avaliaçáo dos estudantes, ao final da atividade de GV/GO, Anastasiou e Alves (2004) levantam algumas considerações: é preciso observar se o grupo demonstrou entendimento acerca do assunto debatido e conseguiu definir ideias relevantes durante a apresentação; também é fundamental observar a segurança do grupo acerca do tema debatido; observa-se ainda a integração do grupo observador ao longo da exposição; verifica-se, ainda, se os estudantes conseguiram relacionar $\mathrm{o}$ assunto debatido à realidade. 


\section{Materiais e métodos}

Um foco de interesse nesta pesquisa foi o de conhecer como os estudantes se comportariam diante do método utilizado, a fim de avaliar se os resultados do método ativo seriam significativos, em relação aos métodos tradicionais. Diante desse resultado, é que pudemos avaliar o nível de engajamento, envolvimento e autonomia apresentados pelos estudantes, uma vez que a metodologia ativa busca ter no estudante o agente principal da aprendizagem.

O cenário da pesquisa foi uma Escola, mantida pelo Serviço Social da Indústria-SESI, departamento regional do Amapá, localizada na cidade de Macapá, no Estado do Amapá.

O público-alvo das atividades desta pesquisa foram os estudantes do $6^{\circ}$ ano do Ensino Fundamental II-Anos Finais, totalizando cerca de 30 estudantes, com idade entre 10 e 12 anos, nomeados neste estudo como 'Aluno 1', 'Aluno 2', e consecutivamente. Antes de se iniciar a pesquisa, buscou-se a autorização para esta junto à escola e aos pais e responsáveis pelos estudantes, para evitar quaisquer prejuízos ou danos para qual quer uma das partes. Optou-se por tal turma por esta ser o início de um ciclo de aprofundamento científico, os estudantes já haviam entrado em contato com as primeiras informaçôes acerca do que é ciência, por meio da disciplina com a mesma nomenclatura, no Ensino Fundamental I, agora, estão se preparando para ampliar esses conhecimentos

Compreende-se, nesta pesquisa, a importância de incutir desde cedo nos estudantes o interesse pela pesquisa científica e as técnicas que tornam possível sua realização, para que cheguem às séries mais avançadas com conceitos mais profundos e maduros acerca das informaçôes necessárias para a compreensão da disciplina.

A pesquisa foi realizada no $3^{\circ}$ bimestre do ano de 2019, na unidade curricular de Ciências Naturais, abrangendo um total de 12 encontros, nesses encontros foram realizadas adaptaçóes das estratégias 'World Café' e GV/GO. Nesses encontros, foram trabalhados conceitos relativos à ecologia, de forma que os estudantes pudessem agir em torno dos problemas ecológicos que identificaram nos ambientes por onde transitam, por meio das metodologias ativas escolhidas para a pesquisa.

A realizaçáo do 'World Café' ocorreu em cinco encontros. O objetivo do primeiro encontro foi explanar sobre a estratégia ativa 'World Café' e realizar a divisão dos estudantes em equipes para leitura das notícias referentes ao objeto de estudo água. Assim, nesse primeiro encontro, os estudantes foram divididos em cinco equipes em sala de aula, com a escolha de um representante por equipe, que seria o líder, responsável pela organizaçáo da equipe, motivando-a a participar das atividades. Logo após, foram explanados o objetivo e as etapas da estratégia 'World Café' e a importância da participação de todos para o bom andamento da aula, e também as diretrizes do método ativo.

Nesse mesmo encontro, os estudantes receberam os cinco textos os quais teriam de ler em equipe. Esses textos selecionados eram reportagens que destacavam a água relacionada ao estado do Amapá, sendo os disparadores para as discussóes. 
O objetivo do segundo encontro era a realização da leitura do texto teórico e discussão sobre os conceitos entre as equipes. Nesse momento, as equipes receberam também textos teóricos sobre as temáticas abordadas nos textos anteriores e fizeram a leitura e discussão, com a supervisão do professor pesquisador, assim tirando as dúvidas e fazendo a mediação com os discentes, para que cada equipe conseguisse discutir os textos e, no final, fizeram a socialização com as demais equipes.

No final da aula, explicou-se a etapa seguinte, que seria o rodízio entre as equipes, e solicitou-se que cada integrante trouxesse um lanche para a conversa nas equipes. Explicou-se também que seria sorteado um tema dentre os cinco que foram estudados para cada equipe na aula seguinte. $\mathrm{O}$ objetivo do terceiro encontro era desenvolver o método do 'World Café com o rodízio entre as equipes. Para esta aula, o espaço foi organizado pelo professor pesquisador, para que o encontro ocorresse de maneira efetiva e sem atrasos.

O professor iniciou a explicação de como funcionaria a dinâmica, destacando que cada equipe teria um "anfitriāo" e que, por sorteio, cada equipe ficaria com um dos cinco temas estudados por todos para realizar as rodadas de diálogo, com duração entre 15 e 20 minutos cada. As equipes receberam papéis pardos e canetas marcadoras coloridas. O professor também tinha o papel de encorajar tanto os anfitrióes, quanto aos demais participantes a escreverem, rabiscarem e desenharem ideias-chave sobre o papel.

$\mathrm{Na}$ primeira rodada, cada equipe fez a discussão e suas anotaçôes no papel, logo após, o anfitrião ficou em sua mesa, enquanto os demais estavam em rodízio organizado, levando suas ideias para o novo anfitriáo, dialogando com este e contribuindo com anotaçóes no papel. Após percorrer todas as equipes, retornaram a sua equipe inicial. Em tais rodadas, os anfitriōes foram orientados a receber os seus convidados e a conversar com eles, para que a contribuição seja efetiva, pois seria necessária essa construção coletiva.

Ao final, foi solicitado que cada equipe que se organizasse para a explanação das sintetizaçóes das rodadas, assim, as equipes deveriam buscar fotos, imagens, filmagens que complementassem sua explanação sobre os assuntos, que ficaria para as duas aulas seguintes. Por fim, o objetivo dos últimos encontros, as aulas quatro e cinco, era a explanação sobre os assuntos e discussões no 'World Café'. Essa foi a última etapa da metodologia ativa.

Cada equipe socializou, por meio de uma plenária, as descobertas e discussóes realizadas. Cada equipe mostrou o papel produzido e também fez uma apresentação com uso de imagens, fotos e vídeos sobre a temática da equipe, sendo disponibilizados de 20 a 30 minutos por equipe. Além disso, o professor estimulou as outras equipes a contribuírem nas apresentaçôes das equipes, a fim de enriquecerem a plenária e desenvolverem os princípios da metodologia ativa. Antes de finalizar, os estudantes responderam a um questionário sobre a metodologia e a aplicação.

Os dados recolhidos foram estudados a partir de uma análise descritiva. Esse tipo de análise utiliza a estatística descritiva para organizar, resumir e descrever os 
aspectos relevantes de um determinado conjunto de características observadas nos objetos de estudo ou comparar tais características entre os conjuntos encontrados.

Dessa maneira, nesta pesquisa, os estudantes responderam a questionários com perguntas abertas acerca da metodologia vivenciada por eles. Suas respostas foram analisadas a partir da análise descritiva, conforme explica Reis e Reis (2002): muitas das respostas se repetiam ou podiam ser padronizadas semanticamente, o que possibilitou a construção de categorias, distribuídas conforme o percentual de repetição de respostas e respostas-padrão, podendo-se, assim, por meio de comparaçáo entre as respostas.

Já a estratégia GV/GO realizou-se em sete encontros, os quais serão detalhados a seguir. O objetivo do primeiro encontro era explanar sobre o método ativo G.V (Grupo de Verbalização) e G.O (Grupo de Observaçáo). Assim, nesse primeiro encontro, os estudantes foram orientados sobre a metodologia ativa, destacando o objetivo e as etapas da estratégia G.V e G.O, além de expor a importância da participaçáo de todos para o bom andamento da aula, e as diretrizes da metodologia ativa.

Nesse mesmo encontro, os estudantes receberam o texto: Biomas do Brasil: conheça as 9 principais ameaças ${ }^{3}$, tendo de realizar a leitura em equipe, sendo este texto o foco para as discussôes.

No segundo e terceiro encontros, o objetivo foi realizar a leitura do texto teórico e a discussáo sobre os conceitos entre as equipes. Neste momento, os estudantes fizeram a leitura e discussão, com a supervisão do professor pesquisador, que tirava as dúvidas e fazia a mediação entre discentes, de forma que todos os estudantes fizessem a leitura. Ao final da aula, o professor explicou a etapa seguinte e dividiu os estudantes para aplicar o método G.V e G.O, destacando a importância da participaçáo de cada estudante.

Nos encontros quatro e cinco, o objetivo foi desenvolver o método ativo G.V (Grupo de verbalização) e G.O (Grupo de Observação). Para tais encontros, o espaço foi organizado pelo professor pesquisador para que a atividade ocorresse de maneira efetiva e sem atrasos.

O professor iniciou a explicação de como funcionaria a dinâmica do método, destacando como seria cada rodada do G.V e G.O. Também foi realizada a divisão na turma em dois grupos: Grupo 1 = Grupo de verbalização $(\mathrm{GV})$; e Grupo 2 = Grupo de observação (GO), por meio de sorteio.

Após a divisão da turma, foram realizadas as orientaçôes quanto ao total de rodadas, que seriam 6. Estabeleceu-se também o tempo de cada rodada, que seria entre 10 e 15 minutos. Em seguida, organizou-se os dois círculos: o GV no grupo interno; e o G.O no grupo externo.

3 https://www.letrasambientais.org.br/posts/biomas-do-brasil:-conheca-as-9-principais-ameacas. 
No grupo GO, os estudantes estavam com um material para realizar as anotaçóes sobre o tema e formularem questôes sobre o conteúdo abordado. No GV, os estudantes iriam escolher dois estudantes que fariam a organização das falas.

Logo após essa organização das equipes, começou-se a efetivação da metodologia ativa, em que cada equipe teria seu papel e trocaria na segunda rodada, quem era GO seria GV na segunda rodada, e assim sucessivamente. O professor deixou claro que não seria necessário seguir uma ordem da discussão sobre o tema: Biomas do Brasil: conheça as 9 principais ameaças.

Nesse momento, o professor conduziu a primeira rodada, realizando uma sensibilização da turma, realizando uma pergunta disparadora: Quais os principais problemas que acometem os biomas do Brasil? Enquanto o GV falava, o GO apenas observava e não podia se pronunciar, sendo os estudantes orientados a apenas prestar atenção à discussão do $\mathrm{GV}$, podendo o $\mathrm{GO}$ realizar anotaçóes e perguntas a serem respondidas nas demais rodadas. Ao final das seis rodadas, foi realizada uma autoavaliação, destacando a participaçáo de cada estudante.

Nos encontros seis e sete, o objetivo era fazer a explanaçáo sobre o assunto: Biomas do Brasil: conheça as 9 principais ameaças e discussōes do GV/GO. Tais aulas foram a última etapa do método, em que a turma foi dividida em cinco equipes e fizeram a construçáo de cartazes. Cada equipe socializou, por meio de uma plenária, as descobertas e discussóes realizadas. Cada equipe mostrou o papel produzido e também fez uma apresentaçáo, sendo disponibilizado de 10 minutos por equipe. Além disso, o professor estimulou as outras equipes a contribuírem nas apresentaçôes das equipes, afim de enriquecer a plenária e desenvolver os princípios do método ativo. Antes de finalizar os estudantes responderam um questionário sobre a metodologia e a aplicaçáo.

\section{Resultados e discussáo}

\section{'World Café'}

Aplicou-se, ao final da atividade 'World Café, um questionário, ao qual os estudantes deveriam responder, a partir de suas próprias opinióes, como avaliavam a metodologia aplicada, o seu próprio desempenho, etc. O questionário fora construído por perguntas de caráter aberto e as respostas foram recolhidas e comparadas por meio da ferramenta de software Infogram.com. A partir dessa análise de dados, foi possível perceber que algumas respostas se repetiam ou eram parecidas, da mesma natureza semântica. Assim, por meio dessa comparaçáo entre as respostas, foi possível dar prosseguimento a este estudo.

A primeira pergunta do questionário solicitava que os estudantes fizessem um resumo do que aprenderam na aula. Como resposta, a maioria dos estudantes citou apenas o tema o qual a equipe em que estavam, outros, contudo, enfatizaram temas discutidos por outras equipes. O termo "saneamento básico" foi o mais abordado, citado por 10 estudantes, em seguida, o termo "água", citado por oito 
estudantes. Alguns estudantes correspondiam esses dois termos aos demais temas, o que demonstra que esses estudantes além de aprenderem com o que pesquisaram e discutiram, também aprenderam ouvindo o que os colegas tinham a dizer, e assim, conseguiram relacionar vários temas, que antes pareciam independentes:

Aprendi com minha equipe sobre áreas de ressaca, várias coisas que eu nem sabia, isso nos ajudou a nos aproximar mais um dos outros e interagir a esse tema. Aprendi que áreas de ressaca são áreas úmidas, com reservatórios cheios de água, que podem ser poluidas ou não, e que as águas dos rios avançam sobre as casas (Aluno A, 11 anos).

Sobre os reflexos do saneamento na sociedade, aprendemos sobre o acesso de abastecimento de água, sobre o por quê precisamos de água limpa, a população precisa de água encanada já na casa, de serviços de esgoto. A situação continua precária, pois apenas 50,6\% da população é atendida (Aluno B, 12 anos)

A segunda pergunta do questionário solicitava que avaliassem a estratégia 'World Café'. Grande parte da turma atribuiu à estratégia a qualidade "legal", citada por 10 estudantes; além desta qualidade, atribui-se outros adjetivos, tais como: divertido (seis), bom (quatro), diferente (quatro), dinâmico (dois), interessante (dois), bacana (um), gostei (um). Juntos, tais adjetivos correspondem a 97\% das respostas, apenas um estudante a considerou "mais ou menos".

Percebe-se, dentre as repostas dos estudantes, que houve identificação e afinidade destes com a estratégia. Analisando a relação semântica das respostas dadas pelos estudantes, nota-se o fundo afetivo diretamente relacionado ao caráter didático. A educaçáo deve desenvolver-se juntamente à afetividade, pois, um ambiente em que o estudante não se sinta acolhido, não se sinta bem, normalmente, será pouco favorável ao seu desenvolvimento cognitivo, pois náo encontrará motivaçóes para aprender. Neste ponto, Moran (2014), defende a importância da relação da efetividade e o desenvolvimento das potencialidades humanas:

A afetividade é um componente básico do conhecimento e está intimamente ligada ao sensorial e ao intuitivo. Ela se manifesta no acolhimento, na empatia, na inclinação, no desejo, no gosto, na paixão, na ternura, na compreensão para consigo mesmo, para com os outros e para com o objeto do conhecimento. A afetividade dinamiza as interaçóes, as trocas, a busca, os resultados. Facilita a comunicação, toca os participantes, promove a união. O clima afetivo prende totalmente, envolve plenamente, multiplica as potencialidades (p. 66).

Contudo, as metodologias ativas, por serem diferentes das aulas tradicionais, é natural que alguns estudantes não queiram participar, é natural um certo impacto na rotina escolar, dado o forte teor dinâmico da metodologia. Ademais, os estudantes não conheciam a estratégia aplicada, o 'World Café', sendo esta uma experiência diferenciada em sua vida escolar. Alguns estudantes preferem aulas tradicionais, pois estas não trazem esse momento da fala, do debate, abrindo espaço para a timidez, o que comprova o quanto o ensino tradicional está arraigado na sociedade brasileira e o quanto o papel passivo do estudante está naturalizado entre os estudantes e professores, ao ponto de sua autoestima intelectual estar muito baixa, e náo 
quererem falar em público, entre seus colegas, sobre assuntos relacionados à aula, por medo de estar falando algo errado.

Percebe-se, então, uma certa relutância, por parte de alguns estudantes, em aceitar o papel ativo exigido pela estratégia, e também a dificuldade em assimilar a nova estratégia. Dessa forma, reflete-se que o desafio assumido pelos educadores é despertar nesses estudantes motivos para que queiram aprender, tornando as aulas mais interessantes e trabalhando com conteúdos relevantes para o seu cotidiano, tornando a sala de aula um ambiente estimulante para a aprendizagem (SANTOS, 2008).

A terceira pergunta questionava se o método levou os estudantes a terem novas ideias. Para se chegar ao resultado, reunimos respostas positivas e negativas e as de meio-termo. Uma parcela considerável turma, 23 estudantes, afirmou que a estratégia ajudou a ter novas ideias, alguns estudantes atribuíram o fato à troca de ideias e experiências ao longo das discussões:

Sim, porque assim nós aprendemos a como ter novos tipos que nos ajudou a aprender mais rápido (Aluno C, 11 anos).

Sim, tanto em debates de classe, como em cartazes e discussóes sobre problemas da sociedade (Aluno D, 12 anos).

Sim, pois em cada grupo eu respondia as perguntas e isso me ajudou a aprender $e$ ter mais ideias (Aluno E, 11 anos).

Ademais, dois estudantes utilizaram o meio-termo "não muito" e um estudante afirmou que não, estes atribuíram a resposta ao fato de muitas ideias já estarem nos cartazes, assim, não havia mais tanto no que pensarem:

Não muito (Aluno F, 12 anos).

Não muito, porque foi uma atividade bem diferenciada (Aluno G, 11 anos).

Não, porque as ideias já estão no cartaz (Aluno H, 11 anos).

Apesar de uma pequena parcela afirmar que a estratégia não ajuda a ter novas ideias, a maior parte da turma apresentou um resultado significativo, o que confirma que o fato de os estudantes poderem discutir entre si, pesquisar, montar seus cartazes e fazer suas apresentaçóes traduz-se num método eficaz para que os estudantes aprendam mais e com ajuda de seus pares.

Atribui-se a essa interação entre os estudantes o fato de os estudantes gerarem diversos níveis de conhecimentos entre eles, já que os estudantes poderiam se ajudar e trocar ideias, fato este que muitos estudantes consideraram ser uma das causas de seu aprendizado. Segundo Leite e Ramos (2017, p. 84):

A interação aluno-aluno é rica em informações, pois gera discussōes valiosas, que levam a reflexões sobre o conteúdo apresentado, a aprendizagem é mútua, os que sabem ajudam os que não sabem, são estimulados a buscarem novas formas de conhecimento e a lidar com diferentes contextos sociais e culturais. 
Corroborando essa questáo, Quintilhano (2020) enfatiza que as metodologias ativas podem ser responsáveis por uma maior interação, o que permite que o estudante seja responsável pelo próprio ensino, mas a autora alerta ainda que tais atividades exigem do professor maior tempo de preparo das aulas, e também uma constante dedicação para formular e reformular as atividades, uma vez que estas devem corresponder às necessidades dos alunos, e cada estudante, cada turma, traz uma necessidade, uma característica, uma habilidade diferente. De nada adianta aplicar a mesma metodologia, utilizando as mesmas ferramentas e os mesmos recursos em turmas diferentes, pois o fato de uma turma ter se desenvolvido muito bem com uma atividade, não significa que o mesmo resultado será obtido com outras turmas. Por isso, a avaliação constante da metodologia é tão necessária.

Ademais, conforme aponta Gama (2015), o estudante habituou-se a agir de forma automática em relação à educação. Ele vai para a escola, escuta professor, estuda para as provas a fim de conseguir uma boa nota, depois, esquece-se de cada palavra dita pelo professor. Por isso, esse mesmo autor fala que, as metodologias ativas têm como mudar essa rotina, dando relevância a todo conteúdo passado em sala de aula, assim, o conhecimento deve ser fixado na memória, e o único caminho para isso é pondo o conhecimento em prática.

O engajamento do aluno em relação a novas aprendizagens, pela compreensão, pela escolha e pelo interesse, é condiçáo essencial para ampliar suas possibilidades de exercitar a liberdade e a autonomia na tomada de decisóes em diferentes momentos do processo que vivencia, preparando-se para o exercício profissional futuro (BERBEL, 2011, p.29).

$\mathrm{Na}$ área de Ciências Naturais, entáo, nada mais eficiente para o aprendizado do que a prática do conhecimento, o ver de perto, o construir, o experimentar. E foi justamente isso o que os alunos da pesquisa fizeram, estiveram junto aos problemas em debate e, por si mesmos, pensaram e propuseram soluçôes para os desafios.

A quarta pergunta questionava sobre a participaçáo do estudante e da equipe. Apenas três estudantes consideraram a sua participação mediana, pelo fato de ter falado pouco, alguns atribuíram essa qualidade ao fato de serem tímidos ou de náo ter tido espaço para falar. Um estudante atribuiu a qualidade "bastante corrida", devido ao fato da intensa participação em todas as tarefas. Dessa forma, a maior parte dos estudantes afirmou ter tido uma participação significativa na atividade, seja na discussão dos temas, nas apresentaçôes, na confecçáo dos cartazes.

Assim, 14 estudantes avaliaram sua participação como "boa", quatro estudantes avaliaram como "legal" e quatro estudantes responderam "participei bastante". Comparando este resultado ao da segunda pergunta, percebe-se que os estudantes gostaram da atividade não só pelo seu caráter lúdico, mas porque puderam participar ativamente da construção do conhecimento.

A estratégia 'World Café' pode ser considerada como um desafio, no qual os estudantes tiveram de mostrar suas ideias, debater, discutir com seus pares, etc. Acredita-se que, como afirma Freire (1996), o que impulsiona a aprendizagem é a superação de desafios, resolvendo problemas e construindo conhecimentos novos a 
partir de conhecimentos e experiências prévias. Para Freire (1996) é preciso trazer à superfície a realidade em que os estudantes vivem, para, então, a partir dela, desenvolver novos conhecimentos.

Ao longo da aplicação da estratégia, os estudantes discutiam os problemas do seu contexto de vivência, relacionados aos temas discutidos em sala de aula, e a partir desses temas, os estudantes relacionavam uma ideia com outros contextos, chegando a conclusóes sobre o assunto discutido. Essa troca de experiências e ideias resultou, então, em diversos níveis de aprendizagens.

É justamente esse diálogo entre os estudantes, essa troca de experiências e conhecimentos que defendemos aqui como autonomia em sala de aula: a capacidade de os estudantes conseguirem demonstrar que também são construtores de conhecimento, que podem ser protagonistas de sua aprendizagem. Proença (2016) corrobora com essa discussão:

A autonomia deve ser considerada, também, em relação às consequências do processo, pois na mesma proporção em que todos estáo envolvidos no processo de aprendizagem, a responsabilidade, os "ônus" e os "bônus" de todo o percurso formativo também são compartilhados, tornando-se uma construção compartilhada (p. 17).

Perguntados se gostariam de mais aulas desse tipo, apenas um estudante afirmou não querer tal atividade outra vez, o que corresponde à resposta-padrão "mais ou menos" da segunda pergunta (se gostaram da estratégia), este estudante afirmou, em outras respostas, preferir as aulas tradicionais, pois não precisa interagir com a turma. No entanto, a esta pergunta, este mesmo estudante que respondeu não querer novamente aulas com o método, atribuiu-lhe uma qualidade positiva em sua justificativa.

Em relaçáo aos problemas de adaptaçáo à metodologia ativa de ensino, reiteramos que esta se relaciona à quebra de uma educação tradicional, uma vez que o estudante está, desde a mais tenra idade, acostumado a receber passivamente o conteúdo (MORÁN, 2014). A respeito dessa negação, não-aceitação e resistência de muitos estudantes, dado que metodologia ativa deve representar um método fomentador de conhecimento, por trabalhar habilidades diversas e necessárias ao educando, como comunicação, cooperação e ética, insistimos na necessidade de avaliação e reelaboraçáo constante das metodologias.

No que diz respeito às justificativas dadas pelos estudantes, obtivemos $100 \%$ de respostas positivas ao método 'World Café. A resposta que recebeu maior destaque foi "ajuda a trabalhar em equipe", correspondendo a cinco respostas. Uma possível explicação para isso é que, nas aulas tradicionais, os estudantes não são incentivados a trabalhar em equipe, a maioria das atividades são individuais, e é uma necessidade do ser humano conviver em grupo, assim, muitos estudantes se identificaram com o método pois tiveram a oportunidade de interagir com seus pares em uma atividade, ao mesmo tempo lúdica e produtiva. 
Outra resposta que merece destaque são as parcelas "é legal" (quatro respostas) "Mais fácil de aprender" (três respostas) e "ajuda no desempenho" (três respostas), juntas, constituem um número considerável de estudantes que se sentiram beneficiados com a metodologia, pois sentiram que realmente aprenderam os assuntos discutidos, exemplo disso são as correspondências entre temas feitas nas respostas da primeira pergunta. Isso demonstra que o resultado do método foi até agora significativo para o aprendizado dos estudantes, demonstrando-se eficiente enquanto um método de ensino.

Paulo Freire (1987) nos faz refletir acerca desse resultado em relação à avaliaçáo dos estudantes: para o autor, quanto mais os estudantes são problematizados, como seres no mundo e com o mundo, mais desafiados sentir-se-ão; quanto mais desafiados, mais obrigados sentir-se-ão a responder ao desafio; e desafiados, compreendem esse desafio na ação de captá-lo. Assim, compreendemos que a metodologia correspondeu a um desafio para os estudantes, mas que conseguiram superá-lo, compreendê-lo, gerando conhecimentos.

Pediu-se que os estudantes elencassem os pontos positivos do método. Uma parcela considerável apontou o "trabalho em equipe" (11 respostas) e a "interação" (nove respostas) como os pontos positivos desse método. Outra resposta que merece destaque é "aprendizado" (seis respostas). Percebe-se, entáo, que nossos objetivos foram alcançados com este método, pois os estudantes se sentiram à vontade trabalhando em equipe, classificando positivamente essa característica, e ainda destacaram que conseguiram aprender por meio do método. Segundo Morán (2013, p.1):

A aprendizagem é mais significativa quando motivamos os alunos intimamente, quando eles acham sentido nas atividades que propomos, quando consultamos suas motivaçóes profundas, quando se engajam em projetos em que trazem contribuições, quando há diálogo sobre as atividades e a forma de realizá-las.

A próxima pergunta solicitava que os estudantes elencassem os pontos negativos do método. Uma parcela significativa, correspondendo a sete estudantes, afirmou que não há o que mudar na metodologia, pois estavam satisfeitos. A maioria das respostas correspondia mais ao comportamento dos próprios estudantes que à atividade em si: falta de educação dos estudantes (uma resposta), melhorar as apresentaçóes (uma resposta), exagero nos desenhos (uma resposta), mais organização entre as equipes (duas respostas), melhorar os cartazes (uma resposta), o representante ajudar mais (uma resposta), dificuldades com o assunto (uma resposta), trabalho em equipe (três respostas), mais colaboração nos trabalhos (três respostas). Essas características podem variar de uma turma para outra, caso a metodologia seja aplicada em turmas diferentes. Já outras características abordadas devem ser destacadas, ainda que tenham tido um percentual pequeno de respostas: mais perguntas a serem respondidas (duas respostas), mais regras (uma resposta), o líder poder sair da mesa para comer (duas respostas), mudança da equipe muito rápida (uma resposta), pouco tempo (duas respostas), não mudança de grupos (uma resposta). 
Percebe-se, por meio dessas sugestóes, que os estudantes, apesar de satisfeitos com o desenvolvimento da atividade, gostariam de colaborar com o aprimoramento desta, indicando quais pontos o professor poderia modificar para deixá-la mais adequada aos estudantes, por exemplo, alguns estudantes abordaram ora a mudança rápida dos grupos ou o desejo de permanecerem na mesma equipe ao longo da atividade.

Essa fluidez das equipes é o que garante a interação dos estudantes, apontada como o principal ponto de satisfação dos estudantes, mas talvez muitos estudantes não tenham se sentido à vontade com isso, dada a falta de interatividade em seu cotidiano nas aulas tradicionais. $\mathrm{O}$ que nos leva a considerar a importância de mais aulas interativas, que fortaleçam a convivência entre os estudantes, garantindo sua formação plena enquanto seres sociais.

Como aponta Marandino (2008), para que haja total envolvimento dos estudantes na aula, é necessário que se vá além do contato do estudante com os materiais da aula prática, a interação é essencial, tanto física quanto emocional e intelectual. Ademais, para Carvalho (2017), uma aula prática é muito mais que uma demonstração de fenômenos, precisa ser um momento de debate, de partilha de conhecimento. Ademais, Proença (2016) traz como referência Piaget, para defender que "o processo de aprendizagem é decorrente da interaçáo desenvolvida na relaçáo entre o sujeito e o objeto, mediada por outros sujeitos e pela cultura" (p. 17). Dessa forma, depreende-se que a aprendizagem não se dá isoladamente, mas em conjunto, em partilha, envolvendo um todo formado pelos pares e pelo ambiente.

Perguntados acerca do própria participação e aprendizado por meio do método utilizado, os estudantes expressaram suas opinióes. A maior parte das respostas variou entre "boa" (oito respostas) a "moderado" (oito respostas), ainda obtivemos a resposta "mais ou menos" (três respostas) e pequenas variaçóes de avaliação muito positivas, como "legal" (duas respostas), "ajudei bastante" (duas respostas), e "expliquei bem" (uma resposta).

Essa variaçáo se deu devido à forma como os estudantes avaliaram seu próprio nível de participação, alguns que consideraram ter falado pouco, avaliaram sua participaçáo como moderada ou boa, outros que tiveram uma participação mais intensa, com muitas falas se autoavaliaram como "legal", "ajudei bastante", "expliquei bem". Uma pequena parcela avaliou sua participação como "ruim" (uma resposta), "não me esforcei" (uma resposta) e "não participei" (uma resposta), estes se autoavaliaram assim por terem considerado sua participação muito pequena, com uma única fala ou nenhuma, com pouca participação na confecção dos cartazes. No entanto, esta mesma amostra que se autoavaliou negativamente avaliou positivamente o método.

Percebe-se, na autoavaliação dos estudantes um desejo, ou mesmo a necessidade, de uma participação maior, uma vez que estes compreendem que, para que seu desenvolvimento na metodologia seja de fato eficiente e construa conhecimentos, é preciso uma participação maior: 
Pode se afirmar que as práticas pedagógicas com Metodologias Ativas são contributivas para o ensino e aprendizagem, já que os alunos passam de passivos dos conceitos das diversas áreas a autores dos conhecimentos produzidos devido às características intrínsecas nesse método de ensino. $\mathrm{O}$ estudante se depara com um conhecimento, tenta resolver os problemas inerentes e constrói conhecimentos a partir das temáticas propostas (SILVA et al., 2017, p. 36)

Solicitou-se, na nona pergunta, que os estudantes avaliassem a estratégia 'World Café' em comparação às aulas tradicionais. Uma parcela significativa, correspondente a 11 estudantes, afirmou que a aula usando a estratégia 'World Café' foi melhor que as aulas tradicionais, ganham destaque também, com seis respostas cada uma, as características "diferente" e "muito legal". A aula ganhou ainda outros adjetivos positivos, como "interessante" (uma resposta), "participativa" (uma resposta), "ótima" (duas respostas), "muito boa" (uma resposta), "aprendemos melhor" (uma resposta), "aprendemos mais rápido" (uma resposta), etc. No total, 29 estudantes avaliaram a estratégia positivamente, apenas um estudante afirmou preferir as aulas tradicionais.

Alguns estudantes não estão acostumados a tamanho teor de interação, e devido à timidez, com a qual colaboram as aulas tradicionais, preferem aulas em que fiquem isolados em atividades individuais. No entanto, se só se trabalhar de forma individual, valores como o trabalho em equipe, o respeito ao próximo, a empatia, são deixados de lado. $\mathrm{O}$ trabalho grupal vai além de uma aula de conteúdos, pois além dos temas a serem desenvolvidos sobre a disciplina estudada, valores éticos e morais também estão sendo trabalhados na interação entre os estudantes.

Moran (2014) enfatiza a relação do fator emocional e a aprendizagem:

As escolas se preocupam principalmente com o conhecimento intelectual e hoje constatamos que tão importante como as ideias é o equilíbrio emocional, o desenvolvimento de atitudes positivas diante de si mesmo e dos outros, o aprender a colaborar, a viver em sociedade, em grupo, a gostar de si e dos demais (p. 57)

Portanto, é preciso lembrar-se que à escola do século XXI não cabe mais apenas a formaçáo intelectual e mecanizada dos estudantes, mas sua formação ética e cidadã, uma formação humanizada e humanizadora, além de científica. Por isso as metodologias ativas costumam obter bons resultados entre os estudantes, porque os coloca na posição de humanos, seres pensantes e afetivos, capazes de construir e modificar a realidade ao seu redor.

Nesse aspecto, é preciso lembrar que a ciência não se constrói apenas de conhecimentos teóricos sobre física, química ou biologia, mas cabe a ela também aspectos éticos. E preciso fazer ciência pela humanidade, a fim de se obter tecnologias e recursos que tornem a vida no planeta mais confortável, não apenas para o ser humano, mas para que este possa conviver som os demais seres viventes, com a natureza. Então, é preciso trabalhar nos estudantes essa consciência de que fazer ciência é pensar no planeta e no universo de uma forma geral, não apenas nas vantagens que o conhecimento científico trará para o ser humano. 
$\mathrm{Na}$ última pergunta, questionou-se como os estudantes se sentiram ao longo da atividade. A maior parcela da amostra afirmou ter se sentido "bem" (11 estudantes), com destaque também para o adjetivo "feliz" (seis estudantes). Outros adjetivos de valor semântico positivo foram atribuídos: ótimo (duas respostas), privilegiada (uma resposta), surpreso (uma resposta), bom humor (uma resposta), animado (uma resposta), calmo (uma resposta), útil (uma resposta). Três estudantes afirmaram ter se sentido "normal". Percebe-se, nestes adjetivos que a atividade despertou bons sentimentos na maioria dos estudantes, atribui-se esse fenômeno ao fato de poderem interagir, de poderem assumir a liderança, a voz, ter espaço para atuar na sala de aula, trazendo-lhes o sentimento de importância. Apenas um estudante afirmou ter se sentido mal, como justificativa, este estudante afirmou que se sentiu excluído, pois náo teve espaço para a fala. O que nos leva a considerar que é preciso repensar a metodologia de forma que esta beneficie a todos e que dê espaço de fala a todos.

Segundo Moran (2013, p. 1):

A aprendizagem é mais significativa quando motivamos os alunos intimamente, quando eles acham sentido nas atividades que propomos, quando consultamos suas motivaçôes profundas, quando se engajam em projetos em que trazem contribuiçôes, quando há diálogo sobre as atividades e a forma de realizá-las.

Dessa forma, conhecer as necessidades dos estudantes em relação a sua aprendizagem é essencial ao se propor uma nova metodologia de ensino, para que todos sejam contemplados e se sintam incluídos. A escola deve ser um espaço para todos, não importa sua dificuldade, sua habilidade, todos devem ser acolhidos, ao mesmo tempo igualitariamente, mas diferentemente. Parece um paradoxo, mas não se pode tratar igual aos diferentes, pois se estará excluindo aqueles que não se encaixam no padrão; mas não se pode tratar diferente, de modo a excluir os indivíduos, por suas dificuldades, deficiências, características etc. Deve-se buscar, então, um tratamento justo, inclusivo. Pode-se dizer que muito se evoluiu nos últimos vinte anos, nesse sentido, mas ainda estamos longe de dizer que vivemos em uma sociedade justa, que temos escolas adequadas para todos.

\section{GV/GO}

Para realizar a análise do método GV/GO, estudaram-se as respostas dos questionários respondidos por 30 estudantes do $6^{\circ}$ ano, que se dividia em 20 meninas com a média de idade de 11,33 anos, e 10 meninos com a média de idade de 11,4 anos.

Os estudantes responderam a um questionário sobre a metodologia ao final da atividade, visando analisar a percepção deles sobre o desenvolvimento da metodologia. O questionário compunha-se de 10 questóes de caráter aberto, portanto, os estudantes tiveram a liberdade de apresentar sua própria opiniáo nas respostas. Para a análise das respostas, estas foram comparadas, por meio da ferramenta de software infogram.com, a fim de se selecionar os termos de maior destaque, ou seja, aqueles que mais se repetiam. 
A primeira pergunta do questionário solicitava que os estudantes fizessem um resumo do que aprenderam durante a aula em que se utilizou a estratégia GV/ GO. Em suas respostas, os estudantes abordaram diversos temas, até mesmo mais de um tema. Os mais citados foram "desmatamento" (17 respostas), "caça ilegal" (nove respostas), "queimada" (nove respostas) e "ameaças ao bioma" (oito respostas). Notou-se, nas respostas dos estudantes, que eles conseguiam relacionar os diversos temas como causa e consequência um do outro, por exemplo.

Percebe-se, então, certa autonomia entre os estudantes para formular suas respostas. Para Moran (2013, p. 1), "o papel do professor é ajudar os estudantes a ir além de onde conseguiriam fazê-lo sozinhos. Até alguns anos atrás, ainda fazia sentido que o professor explicasse tudo e o estudante anotasse, pesquisasse e mostrasse o quanto aprendeu." Com poucas intervençôes do professor, durante a aula, os estudantes sozinhos conseguiam relacionar suas falas com as de seus colegas, construindo, assim uma rede de conhecimentos.

Na segunda pergunta, solicitou-se que os estudantes formulassem uma opiniáo sobre a metodologia utilizada na aula. Vale enfatizar que eles não conheciam a metodologia antes de sua aplicação. Como resposta, os estudantes utilizaram alguns adjetivos ou expressões adjetivas. Grande parte da turma considerou a estratégia "legal" (11 respostas) e "diferenciada" (nove respostas), entre outros adjetivos, tais como "interessante", com quatro respostas; "bacana", "interativa”, " gostei muito", com três respostas cada um; e "dinâmica" e "bom", com duas respostas cada um.

Considera-se esse resultado como significativo em nosso pesquisa, uma vez que, ao mesmo tempo em que os estudantes consideram a atividade como uma experiência diferenciada, também a consideram "legal", "bom" e "interessante". Tirar os estudantes da rotina da aula tradicional é um desafio que nem sempre pode gerar bons resultados, dessa forma, fazer uma atividade diferente exige bastante preparo. Dessa maneira, retomamos Sahagoff (2019), que afirma que por meio das metodologias ativas o estudante pode ter um maior controle sobre sua aprendizagem, tendo assim uma participação mais efetiva, o estudante tornase protagonista de sua aprendizagem, o que, consequentemente, influencia na sua relação afetiva com aquele momento. Se o estudante sente uma maior liberdade, um maior controle sobre si, sentir-se-á melhor acolhido em sala de aula. Destarte, conforme reflete Moran:

A afetividade é um componente básico do conhecimento e está intimamente ligada ao sensorial e ao intuitivo. Ela se manifesta no acolhimento, na empatia, na inclinação, no desejo, no gosto, na paixão, na ternura, na compreensão para consigo mesmo, para com os outros e para com o objeto do conhecimento (MORAN, 2014, 49).

A terceira pergunta questionava se o método ajudou os estudantes a terem novas ideias. A maior parte da turma, 21 estudantes, afirmou que a atividade ajudou a formular novas ideias, já que podia interagir com os colegas, ouvir as demais opiniōes e compará-las. No entanto, cinco estudantes afirmaram não ter tido novas ideias, pois já haviam dito tudo o que tinha para dizer. 
No que diz respeito à parcela que afirmou ter tido novas ideias, percebe-se a importância do trabalho em grupo e da troca de opinióes e ideias. A proposta da atividade era justamente que um grupo ouvisse, enquanto outro grupo expusesse sua visão sobre determinado assunto, depois se invertiam os papéis, essa interação promove o respeito entre os estudantes, no exercício de se aprender a ouvir para se aprender com o outro.

Segundo Souza e Dourados (2015), dentre as muitas vantagens em se trabalhar com práticas pedagógicas diferentes, está a motivação que o dinamismo das atividades proporciona, bem como a integraçáo do conhecimento, o desenvolvimento do pensamento crítico, e também a interação entre os estudantes e o desenvolvimento de habilidades interpessoais.

Questionados como foi a sua interação e a de sua equipe na atividade, os estudantes responderam por meio de adjetivos e termos adjetivados. As respostas variaram entre "boa" (14 respostas), "muito boa" (quatro respostas), "bem legal" (duas respostas) e "ativa" (uma resposta), "desenvolvemo-nos muito" (uma resposta), e quatro estudantes afirmaram que sua participação foi "mais ou menos". Esses dados revelam que os estudantes foram bem participativos na atividade. A atividade de GV/GO exige bastante autonomia dos estudantes, uma vez que eles devem liderar a discussão, então, os estudantes alcançaram, segundo sua própria avaliação, um bom nível de autonomia.

Dessa forma:

Entende-se, portanto que a metodologia ativa é um processo educativo que encoraja o aprendizado crítico-reflexivo, onde o participante tem uma maior aproximaçáo com a realidade, com isso possibilita uma série de estímulos podendo ocorrer maior curiosidade sobre o assunto abordado, pode-se propor inclusive desafios onde o participante busque soluçôes, obtendo assim uma maior compreensão (CUNHA et al., 2017, p. 50).

Por meio da aplicação de uma metodologia ativa, os estudantes demonstraramse participativos e autônomos, construindo, em suas falas e produçóes, conhecimentos ricos em senso crítico.

Quando perguntados se gostariam de outras aulas utilizando esse mesmo método, as respostas foram quase unânimes em afirmativo, apenas com uma variação usando um meio-termo, um estudante afirmou que prefere que esse tipo de aula só aconteça "às vezes", pois também gosta das aulas tradicionais, embora tenha considerado o método GV/GO muito bom. No entanto, a maior parte da turma afirmou que gostaria de outras aulas como essa e, como justificativa, apresentaram alguns motivos.

A maior parte da turma afirmou querer que a aula se repetisse por ser uma experiência diferente ( 25 respostas). O termo "interação" foi outra característica que recebeu bastante destaque dentre as justificativas dadas, repetindo-se sete vezes entre as respostas dadas, dessa forma, percebe-se a pouca frequência desse elemento no cotidiano escolar desses estudantes. Ao mesmo tempo, observa-se o impacto 
provocado por uma atividade que o traz para a sala de aula: impactos profundamente positivos para o aprendizado dos estudantes.

No entanto, essa resistência de alguns estudantes para aceitar os novos desafios introduzidos pelas metodologias ativas reflete-se nas respostas negativas e na não aceitação de certas atividades diferenciadas, sendo este um fator determinante do sucesso ou fracasso da aplicação da metodologia. Freire (1996) argumenta que, para que o ensino seja efetivado, é fundamental levar em consideração diversos fatores, para manter o estudante ativo em sala de aula. Tais como a rigorosidade metódica, pesquisa, respeito aos saberes dos educandos, criticidade, estética e ética, risco e aceitação ao novo, reconhecimento da identidade cultural, dentre outros. Ademais, corrobora Moran (2014) que é possível ajudar a desenvolver o potencial de cada estudante, respeitando-lhes suas possibilidades e limitaçôes. Mas para isso, é necessário levar em consideração a prática da "pedagogia da compreensão", praticar a "pedagogia da inclusáo", para que mesmo estes estudantes que não se identificaram com a metodologia ativa aplicada não se sintam excluídos por seus pares e pelo professor. Neste caso, o professor também não deve desistir dos métodos inovadores e engessar suas aulas nos métodos tradicionais devido à dificuldade de adaptação dos estudantes, mas procurar subterfúgios para, aos poucos, conseguir ampliar os horizontes de aprendizagem desses estudantes.

Questionados acerca dos pontos positivos da atividade, os estudantes elencaram algumas características. Grande parte da turma se dividiu entre "aprendese mais" (10 respostas) e "interação" (oito respostas), reforçando a ideia da interação na sala de aula, como ela pode colaborar para o aprendizado dos estudantes. Estes também abordaram que "todos sabiam o que falar" (três respostas), "não houve bagunça" (duas respostas), "aprenderam a ouvir a opinião dos outros" (duas respostas), apresentou-se "ideias diferentes" (duas respostas), "todos se ajudavam" (duas respostas), etc.

Esses pontos positivos demonstram que, apesar de o controle da aula estar quase que totalmente nas mãos dos estudantes, eles demonstravam responsabilidade e mantiveram a organização na sala de aula. Isto é, dar autonomia para os estudantes não significa bagunça, o estudante deve ser sempre o protagonista da aula, deve ter voz e espaço para expressar sua visáo de mundo e experiências:

É importante a flexibilidade para o aprendizado fluir, um novo rearranjo no ambiente tradicional da sala de aula, por exemplo, é uma opçáo, posicionando, as carteiras de forma diferente do tradicional, isso contribui para a criaçáo de um ambiente propício para o aprendizado. A possibilidade de cooperação entre os discentes é facilitada quando de modifica esse espaço tradicionalmente arranjado, as mudanças podem proporcionar um clima de aproximação e de ajuda mútua entre os membros da sala de aula (CUNHA et al., 2017, p. 52).

Perguntou-se aos estudantes quais pontos devem ser melhorados na estratégia GV/GO. Dentre as melhorias apontadas, consideramos que apenas duas se referem diretamente à estratégia: "mais tempo" (três respostas) e "poderíamos trabalhar com apresentaçóes (uma resposta). Percebe-se que os estudantes gostariam de passar 
mais tempo envolvidos na atividade, ou preferiam outra forma de se apresentar, favorecendo a fala de todos.

Levando em consideração as opinióes de que alguns estudantes não conseguiram falar ou falaram pouco, consideramos essas sugestôes dos estudantes relevantes, pois demonstra que observaram que nem todos foram favorecidos com o método. Gostaríamos de destacar, no entanto, que o que faz dessa estratégia aplicada uma metodologia ativa náo é apenas fato de os estudantes falarem em suas apresentaçóes, mas a sua participação como um todo, ao longo do desenvolvimento da atividade, sua interação com seus pares, a forma como se envolve na aula:

a metodologia de aprendizagem ativa necessita que o discente faça uso do raciocínio da observação, do entendimento, da reflexão, de forma que este seja um agente ativo e não passivo. Se o discente ouve, ver, pergunta, discute, realiza e até orienta os demais discentes, está exatamente dentro da proposta do termo ativo no universo de aprendizagem (CUNHA et al., p. 51).

Pediu-se que os estudantes avaliassem sua participaçáo e aprendizado com a estratégia. Mais da metade da turma se autoavaliou com os seguintes adjetivos: "boa" (oito respostas), "muito boa" (seis respostas) e "ótima" (duas respostas). Já quatro estudantes afirmaram não ter falado tanto mas, ter aprendido muito. Um estudante avaliou sua participaçáo como muito ruim, e dois estudantes se autoavaliaram como "mais ou menos", e outros dois como "não muito boa".

Os estudantes que se autoavaliaram negativamente enfatizam em suas respostas que falaram muito pouco ou nada, o que explica o fato de alguns estudantes quererem mais tempo ou outras formas de apresentação para que todos tenham oportunidade de falar. Já os que autoavaliaram positivamente comprovaram isso, demonstrando domínio no conteúdo nas respostas da primeira pergunta.

Segundo Cunha et al. (2017), os estudantes sentem-se mais motivados quando percebem o respeito, a amizade, a confiança e o afeto de seus pares. Isso possibilita-lhes um maior interesse pelos estudos, melhorando consideravelmente o seu aprendizado. Moran (2014), explica bem esse fenômeno:

A afetividade é um componente básico do conhecimento e está intimamente ligada ao sensorial e ao intuitivo. Ela se manifesta no acolhimento, na empatia, na inclinação, no desejo, no gosto, na paixão, na ternura, na compreensão para consigo mesmo, para com os outros e para com o objeto do conhecimento (p. 48).

Solicitou-se que os estudantes avaliassem a estratégia em comparação às aulas tradicionais. Uma parcela significativa de 11 estudantes considerou a atividade mais interessante que as aulas tradicionais. A estratégia também ganhou outros adjetivos positivos, tais como "dinâmica" (uma resposta), "legal" (três respostas), "diferente" (três respostas), "especial", (uma resposta) "bacana" (duas respostas), "importante" (uma resposta), etc. Apenas uma resposta divergiu do total de $97 \%$ que afirmou ter preferido a metodologia ativa: um estudante afirma preferir as aulas tradicionais. 
A atividade grupal é crucial para a construção do caráter e de valores fundamentais para a convivência em sociedade e deve, portanto, ser incentivada na escola. Segundo Cunha et al. (2017, p. 54),

Esse espaço interativo e até lúdico proporciona uma esfera de satisfação e motivaçáo tanto para o discente como para o docente, proporcionando assim um aprendizado leve e emocionante, diferente dos métodos tradicionais onde as aulas são em sua maioria cansativas e enfadonhas, com textos intermináveis e arguiçóes vazias, além do absoluto silencio por parte dos discentes.

No entanto, como bem mostra este estudante que afirma preferir as aulas tradicionais, percebe-se que a posição professor-mestre e estudante-passivo já está tão arraigada em nossa sociedade e escolas que se encontra resistência para permanecer nela, não só por parte dos professores, mas por parte dos próprios estudantes também, que já não se sentem à vontade para se impor diante de seus colegas, de expor suas ideias, já não se vem como seres conhecedores e capazes de também construir conhecimentos.

Por fim, na última pergunta, pediu-se que os estudantes avaliassem como se sentiram ao longo da atividade. Como resposta, eles atribuíram algumas qualidades a seus sentimentos. Como resultado, ganham destaque as respostas "bem" (cinco respostas), "muito bem" (quatro respostas), "feliz" (quatro respostas) e "aprendi bastante" (quatro respostas). Esses dados demonstram que a atividade gerou sentimentos positivos nos estudantes.

O fato de poderem dialogar e assumir papéis de liderança da sala de aula foi-lhes bastante significativo, contribuindo com seu aprendizado. Gostaríamos de destacar ainda a qualidade "adulto" (três respostas), que enfatiza o teor de responsabilidade concedida dada a posição assumida por eles na discussão, a atividade fez com que se sentissem maduros por estarem discutindo temas importantes, com pouca ou quase nenhuma interferência do professor.

Assim, de acordo com Benetti e Carvalho (2002), é fundamental fomentar questionamentos para os estudantes acerca dos conteúdos, fazendo-os construir pontos de vista sobre os assuntos trabalhados, instigando a turma, incluindo todos os estudantes. Nesse âmbito, pode-se organizar debates, trabalhos em grupo, pesquisas, soluçóes de problemas.

Para os autores, fazer o estudante sentir-se responsável pela construção do conhecimento, colocando em prática aquilo que já sabe em articulação com o novo saber adquirido é fundamental para dar-lhe autonomia, propiciando-lhe oportunidades de participação, cooperação e vivência com o assunto ensinado. Nesse caminho, o estudante conseguirá a tomar decisóes, fazer julgamentos e tirar conclusóes, sentindo-se atuante em sua aprendizagem (BENETTI; CARVALHO, 2002).

Ao longo do desenvolvimento das atividades do método GV/GO, os estudantes se envolveram e participaram ativamente, pesquisando, discutindo, trocando experiências, expondo opinióes. A aula, enfim, tornou-se um momento de 
diálogos e construção de conhecimento, na qual os estudantes estavam na posição central, no papel de protagonistas.

Disso resultou um aprendizado científico, pois como o demonstraram em suas respostas aos questionários e ao longo das discussóes, tinham domínio do assunto e aprendiam naquele momento a relacionar diversas perspectivas sobre a mesma temática. A grande diferença entre um conhecimento construído e uma informação lida e decorada é que esta se esvai com o tempo, desaparece da memória, já o conhecimento construído fica e soma-se a demais experiências vividas pelo sujeito, gerando outros conhecimentos (FREIRE, 1996).

\section{Consideraçóes finais}

Dadas as dificuldades que os métodos de ensino tradicionais encontram para sanar as necessidades dos estudantes, pode-se dizer que a escola encontra nas metodologias ativas um subterfúgio para recuperar o interesse desse público nas aulas, agregando demais elementos imprescindíveis para sua formação: tais como a autonomia, a responsabilidade, o pensamento crítico, a autoavaliação, o pensamento científico, etc.

As metodologias ativas têm se mostrado eficientes ao redor do mundo no que diz respeito à qualidade do aprendizado dos estudantes. Obvio que, por ser uma área inovadora e uma novidade em nossa cultura escolar, ainda há muito o que se testar e experimentar, a fim de definir o que realmente pode ser uma experiência frutífera para nossos estudantes.

Em nossa pesquisa, abordamos duas estratégias ativas, o 'World café' e o GV/ GO, aplicados a uma turma de $6^{\circ}$ ano do ensino fundamental II, na disciplina de Ciências Naturais. Percebemos, através dos resultados recolhidos, que os métodos corresponderam às nossas expectativas, gerando resultados positivos no que diz respeito à aprendizagem desses estudantes na área de ciências, uma vez que os estudantes conseguiram compreender as problemáticas propostas, comparar as idéias expostas pelos colegas, investigar e aprofundar seus conhecimentos sobre o assunto, e ainda expor o seu conhecimento sobre o tema em destaque. Houve um processo de construção de conhecimento científico que passou por diversas etapas, culminando na geração de conhecimentos diversos.

Ao longo do desenvolvimento das atividades de ambos os métodos, os estudantes se envolveram e participaram ativamente, pesquisando, discutindo, trocando experiências, expondo opinióes. A aula, enfim, tornou-se um momento de diálogos e construção de conhecimento, na qual os estudantes estavam na posição central, no papel de protagonistas.

Disso resultou um aprendizado eficiente, pois como o demonstraram em suas respostas aos questionários e ao longo das discussóes, tinham domínio do assunto e aprendiam naquele momento a relacionar diversas perspectivas sobre a mesma temática. A grande diferença entre um conhecimento construído e uma informação lida e decorada é que esta se esvai com o tempo, desaparece da memória, já o 
conhecimento construído fica e soma-se a demais experiências vividas pelo sujeito, gerando outros conhecimentos.

E respondendo à nossa pergunta, percebemos que as metodologias ativas escolhidas facilitaram a aprendizagem dos estudantes em relação ao conteúdo de ecologia, uma vez que em suas apresentaçóes e materiais desenvolvidos, conseguiram demonstrar de forma proveitosa o que estavam aprendendo. Os estudantes demonstravam domínio e segurança ao expor seus pontos de vistas sobre os assuntos trabalhados em sala de aula e ainda conseguiam relacionar diversos temas. Essa é uma demostraçáo de que um conhecimento importante foi construído entre os estudantes ao participarem das atividades envolvendo as metodologias ativas.

Em suas respostas aos questionários, os estudantes apontaram como aspectos positivos das metodologias, principalmente, a interação, a diversão e a aprendizagem. Os próprios estudantes sentiram que aprenderam, e não há melhor resposta para a avaliaçáo de uma metodologia que a própria autoavaliação dos envolvidos e a demonstração de que estes, de fato, alcançaram os objetivos esperados.

Muitos estudantes, ao defenderem as estratégias que vivenciaram, afirmaram estar cansados das metodologias tradicionais, além de apontarem maior facilidade de aprendizagem com as metodologias ativas. Uma demonstração desse cansaço e saturação são os baixos rendimentos da escola brasileira e a falta de motivaçáo dos estudantes.

Por fim, cabe a reflexão: grande parte dos estudantes avaliou as metodologias ativas como melhores que as aulas tradicionais. $\mathrm{O}$ próprio público alvo das aulas demonstra cansaço em relação à rotina de cópias, leituras sem objetivos, horas e horas sentados em fila. $\mathrm{O}$ resultado disso podemos ver nas notas e no desempenho desses estudantes em nossas salas de aula, muitos estudantes encontram-se desmotivados.

Será que os anseios desse novo público de estudantes do século XXI tem sido correspondido com o ensino tradicional? Acreditamos que é o momento de repensar nossas práticas como professores, para que resgatemos nos estudantes o gosto pelo aprender, como qual já nasceram, mas que foram perdendo devido a rotinas maçantes e pouco motivadoras.

\section{Referências}

ABREU, J. R. P. Contexto Atual do Ensino Médico: Metodologias Tradicionais e Ativas - Necessidades Pedagógicas dos Professores e da Estrutura das escolas. (Dissertação). Porto Alegre: Universidade Federal do Rio Grande do Sul, 2009.

ANASTASIOU, Léa das Graças Camargos; ALVES, Leonir Pessate. Estratégias de ensinagem. In: ANASTASIOU, Léa das Graças Camargos; ALVES, Leonir Pessate (Orgs.). Processos de ensinagem na universidade. Pressupostos para as estratégias de trabalho em aula. 3. ed. Joinville: Univille, 2004. p. 67-100.

BACICH, Lilian; MORAN, José. (orgs.). Metodologias Ativas para uma educaçáa inovadora: uma abordagem teorico-prática. Porto Alegre: Penso, 2018. 
BASTOS, C. C. Metodologias ativas. 2006. Disponível em: <http://educacaoemedicina. blogspot.com.br/2006/02/metodologias-ativas.html>. Acesso em: 24 dez. 2018.

BENETTI, B.; CARVALHO, L. M. de. A. A temática ambiental e os procedimentos didáticos: perspectivas de professores de ciências. In: Encontro "Perspectivas do Ensino de Biologia, 8., 2002, São Paulo. Atas: São Paulo: FEUSP, 2002. 1 CD- ROM.

BERBEL. As metodologias ativas e a promoção da autonomia de estudantes. Semina: Ciências Sociais e Humanas, Londrina, v. 32, n. 1, p. 25-40, jan./jun. 2011.

BRASIL. Ministério da Educação. Secretaria da Educação Básica. Base nacional comum curricular (BNCC). Brasília, DF, 2017. Disponível em: < http://basenacionalcomum. mec.gov.br/abase/ >. Acesso em: dez. 2018.

BRASIL. Secretaria da Educação Fundamental. Parâmetros Curriculares Nacionais: Ciências Naturais. Secretaria de Educação Fundamental. Brasília: MEC/SEF, 1998.

BROWN, J.; ISAACS, D. O World Café: dando forma ao nosso futuro por meio de conversaçôes significativas e estratégicas. São Paulo: Cultrix, 2007.

CASTRO, A. D.. A Trajetória Histórica da Didática. Série Ideias, n.11. São Paulo: FDE, 1991 p.15-25.

CUNHA, G. I. C.; CUNHA, J. I. C.; MONTE, W. S.; JESUS, S. M. S. Metodologias Ativas no Processo de Ensino Aprendizagem: Proposta Metodológica para Disciplina Gestão de Pessoas in SILVA, Andreza R. L; Bieging, Patrícia; Busarello, Raul Inácio (Org.). Metodologia Ativa na Educaçáo. São Paulo: Pimenta Cultural, 2017

FREIRE, P. Pedagogia da Autonomia. Saberes necessários à prática educativa. $51^{\mathrm{a} e d}$. Rio de Janeiro: Paz e terra, 2015.

FREIRE, P. Pedagogia da autonomia: Saberes necessários à prática educativa. 25. ed. São Paulo: Paz e Terra, 1996.

JÓFILI, Z. Piaget, Vygotsky, Freire e a construção do conhecimento na escola. Educação: Teorias e Práticas. v. 2, n. 2, p. 191-208, dez 2002.

LEITE, Lígia Silva; RAMOS, Margareth Braz. A metodologia Ativa no Ambiente Virtual de Aprendizagem in SILVA, Andreza R. L; Bieging, Patrícia; Busarello, Raul Inácio (Org.). Metodologia Ativa na Educaçáo. São Paulo: Pimenta Cultural, 2017.

LOPES, C. A.; MACEDO, E. Currículo de ciências em debate. São Paulo: Papirus, 2016.

LORENZETTI, L.; DELIZOICOV, D. Alfabetizaçáo científica no contexto das séries inicias. Ensaio - Pesquisa em Educação em Ciências, v. 3, n. 1, jun. 2001.

MARANDINO, M. (Org.). Educação em museus: a mediação em foco. São Paulo: Grupo de Estudo e Pesquisa em Educação Não-formal e Divulgação em Ciências, 2008. 
MASETTO, Marcos Tarciso. Competência pedagógica do professor universitário. 2 . ed. São Paulo: Summus, 2012.

MIRANDA, K. K. C. O..; LIMA, S. A..; OlIVEIRA, M. C. V.; TELLES, C. B. $S$. Aulas remotas em tempo de pandemia: desafios e percepçóes de professores e alunos. VII Congresso Nacional de Educaçáo, 2020. Disponível em:< https:// editorarealize.com.br/editora/anais/conedu/2020/TRABALHO_EV140_MD1_SA_ ID5382_03092020142029.pdf>. Acesso em 29 de maio de 2021.

MORAIS; S. P; ROSA, D. Z; FERNANDES, A. A; SENNA, C. N. P. C. Metodologias ativas de aprendizagem: elaboração de roteiros de estudos em "salas sem paredes". In BACICH, Lilian; MORAN, José. (orgs.). Metodologias Ativas para uma educação inovadora: uma abordagem teorico-prática. Porto Alegre: Penso, 2018.

MORAN, José. A Educação que desejamos: Novos desafios e como chegar lá. Campinas: Editora Papirus, 2014.

MORAN, José. Metodologias ativas para uma aprendizagem mais profunda José Moran (2013). Disponível em: http://www2.eca.usp.br/moran/wp-content/ uploads/2013/12/metodologias_moran1.pdf. Acessado em 25 de novembro de 2020.

MORTIMER, E. F.; SCOTT, Phil. Atividade discursiva nas salas de aula de ciências: uma ferramenta sociocultural para analisar e planejar o ensino.(Discourseactivity in thescienceclassroom: a socioculturalanalyticalandplanning tool for teaching).Investigaçóes em ensino de ciências, v. 7, n. 3, p. 283-306, 2002.

OVIGLI, D. F. B.; BERTUCCI , M. C. S. A formação para o ensino de ciências naturais nos currículos de pedagogia das instituições públicas de ensino superior paulistas.

Ciências; Cognição, v. 14, n. 2, 2009. Disponível:<http://www.cienciasecognicao.org/ revista/index.php/cec/article/view/134/92>. Acesso em: 25 de março de 2018.

PROENÇA, Maria Alice. Prática docente. São Paulo: Panda Educação, 2016.

QUINTILHANO, Silvana Rodrigues. Metodologias ativas no ensino superior: Práticas pedagógicas. Jundiaí-SP: Paco e Littera, 2020.

REIS, Edna Afonso; REIS, Ilka Afonso. Análise Descritiva de Dados. Disponível em:< http://www.est.ufmg.br/portal/arquivos/rts/rte0202.pdf> Acessado em 24 de set. 2020.

SAHAGOFF, A. P. C. Metodologias Ativas: Um Estudo Sobre Práticas Pedagógicas IN Metodologias Ativas: práticas pedagógicas na contemporaneidade. Campo Grande: Editora Inovar, 2019. 203p.

SANTOS, J. C. F. dos. Aprendizagem Significativa: modalidades de aprendizagem e o papel do professor. Porto Alegre: Mediação, 2008.

SILVA, A; GARCIA, A. F. G; RIBEIRO, S. F. C; JESÚS, S. F. Metodologias Ativas: um Desafio para o Trabalho da Orientaçáo in SILVA, Andreza R. L; Bieging, Patrícia; 
Busarello, Raul Inácio (Org.). Metodologia Ativa na Educação. São Paulo: Pimenta Cultural, 2017.

SOUZA, C. S.; IGLESIAS, A. G.; PAZIN-FILHO, A. Estratégias inovadoras para

métodos de ensino tradicionais - aspectos gerais. Medicina, v. 47, n. 3, p. 284-292, 2014.

SOUZA, S.C.; DOURADO, L. Aprendizagem baseadas em problema (ABP): um método de aprendizagem inovador para o ensino educativo. Holos, ano 31, v. 5, 2015. 